\title{
Identification, synthesis, and characterization of potential genotoxic impurities of sildenafil citrate drug substance
}

P. Rajesh Reddy ${ }^{1 *}$, Sivanadh Musunuri², D. Rama Sekhara Reddy², V. Subrahmanyam Chittala',

V. N. S. Murthy $P^{1}$ and K. Krishnamohan ${ }^{1}$

\begin{abstract}
Background: Sildenafil is a selective inhibitor of cyclic guanosine monophosphate (cGMP)-specifil phophodiesterase type 5 (PDE5). Sildenafil enhances the effect of nitric oxide by inhibiting phosphodiesterase type 5 , which is responsible for the degradation of cGMP in the corpus cavernosum. The possible genotoxic impurities of sildenafil were synthesized, i.e., sildenafil sulfonyl methyl ester, sildenafil sulfonyl ethyl ester, and sildenafil sulfonyl isopropyl ester. The present work describes the synthesis and characterization of these sulfonyl ester compounds related to sildenafil.

Results: All the synthesized sildenafil sulfonyl esters have proved to be beneficial for the pharmaceutical industry in view of the regulatory importance.

Conclusion: A simple, efficient, and repeatable method was developed for the preparation of sildenafil sulfonyl esters in view of the regulatory importance of the potential genotoxic impurities in the active pharmaceutical ingredient. A detailed study of various impurities in sildenafil was conducted. Different process-related sulfonyl esters in sildenafil were identified, synthesized, and characterized by using various spectroscopic techniques like liquid chromatography-mass spectrometry (LCMS), mass, ${ }^{1} \mathrm{H}$ NMR, and FT-IR. These efforts to synthesize and characterize them effectively have proved to be beneficial.
\end{abstract}

Keywords: Sildenafil, Genotoxic impurities, Sulfonyl esters, Synthesis, Characterization

\section{Background}

Sildenafil is chemically known as 5-[2-ethoxy-5-(4methylpiperazinylsulfonyl) phenyl]-1-methyl-3-n-propyl1,6-dihydro-7H-pyrazolo [4,3-d] pyrimidin-7-one. Sildenafil is used for the treatment of erectile dysfunction in male and it is also used for hypertension, and its citrate salt $\mathbf{1}$ is marketed by Pfizer under the brand names Viagra $^{\circ}$ and Revatio $^{\circ}$

\footnotetext{
*Correspondence: rajeshpeketi1979@gmail.com

'Research and Development Department, Monvi Labs, 3rd floor, Plot No. 97, Rd. Number 9, ALEAP Industrial Area, Gajularamaram, Hyderabad, Telangana 500090, India

Full list of author information is available at the end of the article
}

Impurities present in an active pharmaceutical ingredient (API) will influence drug effectiveness by the change of quality and safety. Impurities more than $0.1 \%$ [1] should be identified and characterized as per the International Conference on Harmonization (ICH) guidelines. To perform, co-injection studies and analytical performance characteristic studies, for example, specificity, linearity, accuracy, precision, limit of detection (LOD), limit of quantification (LOQ), system suitability testing, and relative retention factor [2] impurities, are required.

In view of the regulatory importance of the genotoxic impurities [3-5] in the API, a detailed assessment study 
on potential genotoxic impurities in sildenafil was conducted. The genotoxic structure evolution was further confirmed by Derek and Sarah analysis.

\section{Mutagenic assessment for the synthetic route to sildenafil citrate}

Mutagenic impurity risk assessment perspective, raw materials, reagents, solvents, by-products, related substances, intermediates, and degradation products from the synthetic process of sildenafil citrate were assessed for potential mutagenic assessment by structure activity relationship (SAR) screening using the expert rule-based software Derek Nexus and statistics-based software Leadscope.

The key raw materials, reagents, and impurities of sildenafil citrate have been assessed for structural alert using the DEREK and SARAH software, and the details of sildenafil sulfonyl esters are provided in the following table:

\begin{tabular}{lllll}
\hline S. & Name of the compound & \multicolumn{3}{l}{ In silico analysis for mutagenicity } \\
\cline { 3 - 5 } no. & Derek & Sarah & Leadscope \\
\hline 1. & $\begin{array}{l}\text { Structural } \\
\text { Sildenafil sulfonyl methyl } \\
\text { ester (6) }\end{array}$ & $\begin{array}{l}\text { Structural } \\
\text { alert }\end{array}$ & $\begin{array}{l}\text { Structural } \\
\text { alert }\end{array}$ \\
2. & $\begin{array}{l}\text { Structural } \\
\text { alert }\end{array}$ & $\begin{array}{l}\text { Structural } \\
\text { alert }\end{array}$ & $\begin{array}{l}\text { Structural } \\
\text { alert }\end{array}$ \\
& $\begin{array}{l}\text { Sildenafil sulfonyl ethyl } \\
\text { ester (7) }\end{array}$ & Structural & $\begin{array}{l}\text { Structural } \\
\text { alert }\end{array}$ & $\begin{array}{l}\text { Structural } \\
\text { alert }\end{array}$ \\
3. $\quad \begin{array}{ll}\text { Sildenafil sulfonyl isopropyl } \\
\text { ester }(\mathbf{8})\end{array}$ & & & \\
\hline
\end{tabular}

The daily dose of sildenafil citrate $\mathbf{1}$ is $100 \mathrm{mg}$ for long-term treatment, mutagenic impurity control for individual impurity would be $15 \mathrm{ppm}$, and total impurities would be $50 \mathrm{ppm}$ based on the threshold of toxicological concern (TTC) rule.

During the process development of sildenafil citrate $\mathbf{1}$ in the laboratory, we prepared possible, novel sildenafil sulfonyl-related esters. In the present work, the genotoxic impurities of sildenafil were synthesized and characterized by various spectroscopic techniques.

\section{Methods}

Solvents and reagents were obtained from commercial sources, and these are used without purification. Triethyl orthoformate was purchased from AVRA chemicals. Sildenafil sulfonic acid and sildenafil sulfonyl chlorides are the intermediates received from the Monvi Laboratories having purity $>99 \%$ by HPLC. ${ }^{1} \mathrm{H}$ NMR and ${ }^{13} \mathrm{C}$ NMR spectral data were performed on Bruker Avance 300$\mathrm{MHz}, 500 \mathrm{MHz}$ spectrometer in $\mathrm{DMSO}-\mathrm{d}_{6}$ and $\mathrm{CDCl}_{3}$. The chemical shift values were reported on the $\delta$ scale in parts per million, downfield from tetramethylsilane as an internal standard. IR spectra were recorded in the solid state using a Perkin Elmer FT-IR spectrophotometer. The mass spectrum was recorded using a PerkinElmer PE SCIEX-API 2000. LCMS was recorded by using SCIEX LC-MS/MS system.

\section{Methyl 4-ethoxy-3-(1-methyl-7-oxo-3-propyl-6,7a-dihydro- 3aH-pyrazolo[4,3-d]pyrimidin-5-yl)benzenesulfonate (sildenafil sulfonyl methyl ester 6) \\ Method 1}

To a suspension of sildenafil sulfonic acid 3 (10 g, 25.5 $\mathrm{mmol})$ in trimethyl orthoformate $(20 \mathrm{~mL})$, methanol $(20$ $\mathrm{mL}$ ) was added at room temperature and stirred the reaction mass at reflux for $24 \mathrm{~h}$. After completion of the reaction, the mass was concentrated to remove the solvent. The resulting residue was dissolved in dichloromethane $(50 \mathrm{~mL})$ and washed with DM water (50 $\mathrm{mL})$. Finally, the organic layer was washed with aqueous sodium bicarbonate solution $(50 \mathrm{~mL})$. Concentrated the resulting organic layer and crystallized with ethyl acetate to obtain which colored compound 6 (6.5 g, 63\%)

\section{Method 2}

To a suspension of sildenafil sulfonyl chloride 4 (10 g, $25.38 \mathrm{mmol})$ in dichloromethane $(50 \mathrm{~mL})$,methanol $(1.62$ g, $50.76 \mathrm{mmol})$ and pyridine $(8 \mathrm{~g}, 101.52 \mathrm{mmol})$ were added at room temperature and stirred for $24 \mathrm{~h}$ at $25-30$ ${ }^{\circ} \mathrm{C}$. The reaction mass was washed with water $(100 \mathrm{~mL})$, aqueous hydrochloric acid $(100 \mathrm{~mL})$, and saturated sodium bicarbonate solution $(100 \mathrm{~mL})$ followed by water $(100 \mathrm{~mL})$. The organic layer was concentrated and crystallized with ethyl acetate to obtain white compound 6 (5.2 g, 50\% yield); IR (KBr pellet, $\mathrm{cm}^{-1}$ ): 3338, 1703, 1356, 1255, 1180; ${ }^{1} \mathrm{H}-\mathrm{NMR}$ (DMSO, $300 \mathrm{MHz}$ ): 0.92-0.96 (t, $\left.3 \mathrm{H}, \mathrm{CH}_{3}\right), 1.32-1.36\left(\mathrm{t}, 3 \mathrm{H}, \mathrm{CH}_{3}\right), 1.73-1.75(\mathrm{~m}, 2 \mathrm{H}$, $\mathrm{CH}_{2}$ ), 2.49-2.50 (t, 2H, $\mathrm{CH}_{2}$ ), $3.76\left(\mathrm{~s}, 3 \mathrm{H}, \mathrm{CH}_{3}\right), 4.17$ (s, $3 \mathrm{H}, \mathrm{N}-\mathrm{CH}_{3}$ ), 4.22-4.24 (q, $\left.2 \mathrm{H}, \mathrm{OCH}_{2}\right), 7.40-7.43(\mathrm{~d}, 1 \mathrm{H}$, Ar), 8.00-8.02 (m, 2H, Ar); and HRMS for $\mathrm{C}_{18} \mathrm{H}_{22} \mathrm{~N}_{4} \mathrm{O}_{5} \mathrm{~S}$ : $(\mathrm{M}+\mathrm{H})^{+}$calcd 407.1344 found, 407.1389.

\section{Ethyl 4-ethoxy-3-(1-methyl-7-oxo-3-propyl-6,7a-dihydro- 3aH-pyrazolo[4,3-d]pyrimidin-5-yl)benzenesulfonate (sildenafil sulfonyl ethyl ester 7) Method 1}

To a suspension of sildenafil sulfonic acid 3 (10 g, 25.5 $\mathrm{mmol})$ in trimethyl orthoformate $(20 \mathrm{~mL})$, ethanol $(20 \mathrm{~mL})$ was added at room temperature and stirred the reaction mass at reflux for $24 \mathrm{~h}$. After completion of the reaction, the mass was concentrated to remove the solvent. The resulting residue was dissolved in dichloromethane (50 $\mathrm{mL}$ ) and washed with DM water $(50 \mathrm{~mL})$. Finally, the organic layer was washed with aqueous sodium bicarbonate solution $(50 \mathrm{~mL})$. Concentrated the resulting organic layer and crystallized with ethyl acetate to obtain which colored compound 7 (6 g, 56\%) 


\section{Method 2}

To a suspension of sildenafil sulfonyl chloride 4 (10 g, $25.38 \mathrm{mmol})$ in dichloromethane $(50 \mathrm{~mL})$, ethanol $(2.3 \mathrm{~g}$, $50.76 \mathrm{mmol}$ ) and pyridine (8 g, $101.52 \mathrm{mmol})$ were added at room temperature and stirred for $24 \mathrm{~h}$ at $25-30{ }^{\circ} \mathrm{C}$. The reaction mass was washed with water $(100 \mathrm{~mL})$, aqueous hydrochloric acid $(100 \mathrm{~mL})$, and saturated sodium bicarbonate solution $(100 \mathrm{~mL})$ followed by water $(100$ $\mathrm{mL}$ ). The organic layer was concentrated and crystallized with ethyl acetate to obtain white compound 7 (5 g, 47\% yield); IR (KBr pellet, $\mathrm{cm}^{-1}$ ): 3305, 1692, 1356, 1245, 1182; ${ }^{1} \mathrm{H}-\mathrm{NMR}$ (DMSO, $300 \mathrm{MHz}$ ): 0.92-0.96 (t, 3H, $\mathrm{CH}_{3}$ ), 1.21-1.26 (t, 3H, $\left.\mathrm{CH}_{3}\right), 1.32-1.36\left(\mathrm{t}, 3 \mathrm{H}, \mathrm{CH}_{3}\right), 1.73-1.75$ (m, 2H, $\mathrm{CH}_{2}$ ), 2.76-2.81 (t, 2H, $\left.\mathrm{CH}_{2}\right), 4.12-4.24(\mathrm{~m}, 7 \mathrm{H}$, $\mathrm{N}-\mathrm{CH}_{3}$ and $2 \times \mathrm{OCH}_{2}$ ), 7.38-7.42 (d, $\left.1 \mathrm{H}, \mathrm{Ar}\right), 7.99-8.01$ (m, 2H, Ar); MS $m / z: 421.1561\left[(\mathrm{M}-\mathrm{H})^{-}\right]$HRMS for $\mathrm{C}_{19} \mathrm{H}_{22} \mathrm{~N}_{4} \mathrm{O}_{5} \mathrm{~S}:(\mathrm{M}+\mathrm{H})^{+}$calcd 421.1501 found, 421.1564 .

\section{Isopropyl 4-ethoxy-3-(1-methyl-7-oxo-3-propyl-6,7a-} dihydro-3aH-pyrazolo[4,3-d]pyrimidin-5-

\section{yl)benzenesulfonate (sildenafil sulfonyl isopropyl ester 8 )}

\section{Method 1}

To a suspension of sildenafil sulfonic acid 3 (10 g, 25.5 $\mathrm{mmol})$ in trimethyl orthoformate $(20 \mathrm{~mL})$, isopropyl alcohol $(20 \mathrm{~mL})$ was added at room temperature and stirred the reaction mass at reflux for $24 \mathrm{~h}$. After the completion of the reaction, the mass was concentrated to remove the solvent. The resulting residue was dissolved in dichloromethane $(50 \mathrm{~mL})$ and washed with DM water (50 $\mathrm{mL})$. Finally, the organic layer was washed with aqueous sodium bicarbonate solution $(50 \mathrm{~mL})$. Concentrated the resulting organic layer and crystallized with ethyl acetate to obtain which colored compound 8 (6.5 g, 63\%)

\section{Method 2}

To a suspension of sildenafil sulfonyl chloride 4 (10 g, $25.38 \mathrm{mmol})$ in dichloromethane $(50 \mathrm{~mL})$, isopropanol $(3$ g, $50.76 \mathrm{mmol})$ and pyridine $(8 \mathrm{~g}, 101.52 \mathrm{mmol})$ were added at room temperature and stirred for $24 \mathrm{~h}$ at 25-30 ${ }^{\circ} \mathrm{C}$. The reaction mass was washed with water $(100 \mathrm{~mL})$, aqueous hydrochloric acid $(100 \mathrm{~mL})$, and saturated sodium bicarbonate solution $(100 \mathrm{~mL})$ followed by water $(100 \mathrm{~mL})$. The organic layer was concentrated and crystallized with ethyl acetate to obtain white compound $\mathbf{8}$ (5.5 g, 50\% yield); IR (KBr pellet, $\mathrm{cm}^{-1}$ ): 3310, 1706, 1330, 1248, 1179; ${ }^{1} \mathrm{H}-\mathrm{NMR}$ (DMSO, $300 \mathrm{MHz}$ ): 0.91-0.96 (t, $\left.3 \mathrm{H}, \mathrm{CH}_{3}\right), 1.23-1.25\left(\mathrm{~d}, 6 \mathrm{H}, 2 \times \mathrm{CH}_{3}\right), 1.32-1.36(\mathrm{t}, 3 \mathrm{H}$, $\left.\mathrm{CH}_{3}\right), 1.70-1.78\left(\mathrm{~m}, 2 \mathrm{H}, \mathrm{CH}_{2}\right), 2.76-2.81\left(\mathrm{t}, 2 \mathrm{H}, \mathrm{CH}_{2}\right)$,

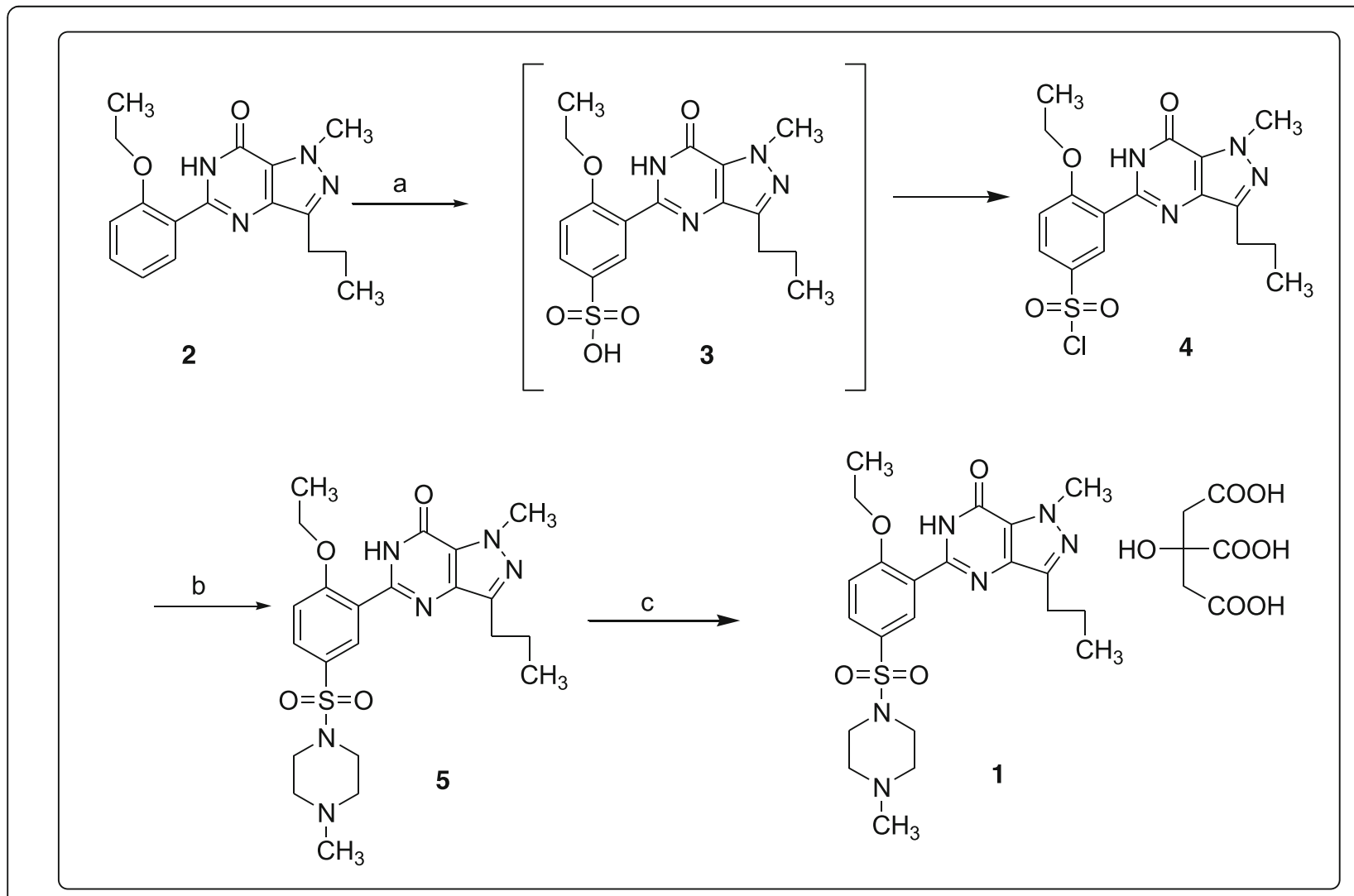

Scheme 1 Reported synthetic scheme of sildenafil citrate1. Reagents and conditions: (a) chlorosulfonic acid, (b) N-methylpiperazine and dichloromethane; and (c) citric acid, water, and methanol 


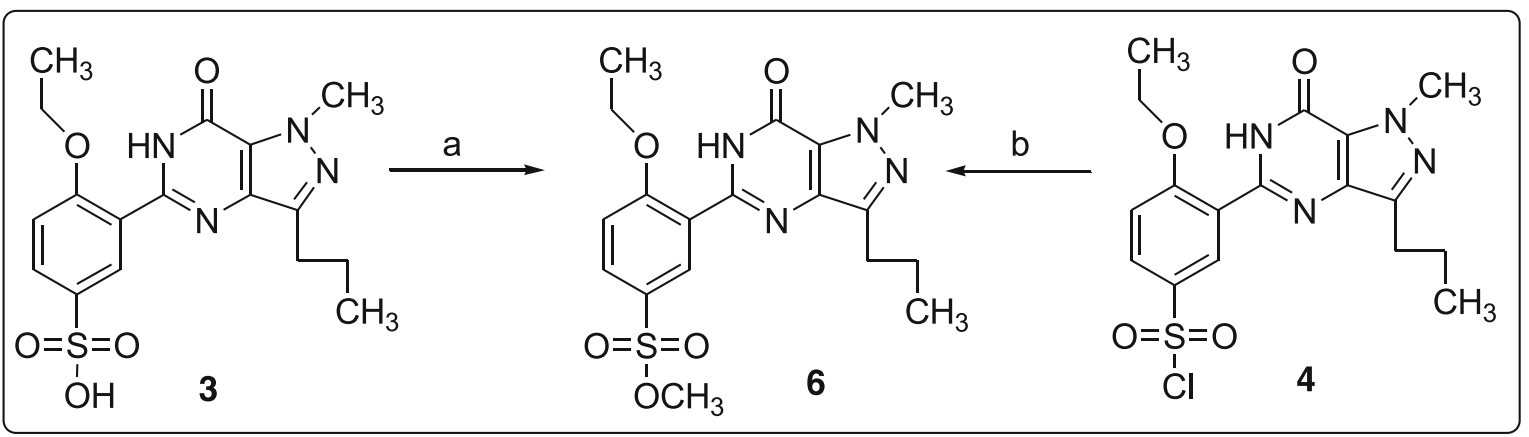

Scheme 2 Synthetic scheme of sildenafil sulfonyl methyl ester $\mathbf{6}$. Reagents and conditions: (a) trimetyl orthoformate, methanol, and dichloromethane and (b) pyridine, methanol, and dichloromethane

4.17 (s, 3H, $\left.\mathrm{CH}_{3}\right), 4.21-4.24\left(\mathrm{q}, 2 \mathrm{H}, \mathrm{OCH}_{2}\right), 4.70-4.72(\mathrm{~m}$, $\left.1 \mathrm{H}, \mathrm{CH}\left(\mathrm{CH}_{3}\right)_{2}\right), 7.37-7.40(\mathrm{~d}, 1 \mathrm{H}, \mathrm{Ar}), 7.98-8.01(\mathrm{~m}, 2 \mathrm{H}$, Ar); $\mathrm{C}_{20} \mathrm{H}_{26} \mathrm{~N}_{4} \mathrm{O}_{5} \mathrm{~S}:(\mathrm{M}+\mathrm{H})^{+}$calcd 435.1657 found, 435.1703 .

\section{Results}

Sildenafil citrate 1 has been synthesized by known literature methods [6-8]. Our process for the synthesis of sildenafil citrate $\mathbf{1}$ is shown in Scheme 1. Sildenafil was prepared by reacting 5-[2ethoxyphenyl]-1-methyl-3-n-propyl-1,6-dihydro- $1 \mathrm{H}$ pyrazolo [4,3-d] pyrimidin-7-one (sildenafil cyclized) 2 with chlorosulfonic acid to produce 5-(5-chlorosulfonyl-2-ethoxyphenyl)-1-methyl-3-propyl- $1 \mathrm{H}$-pyrazolo [4,3,-d] pyrimidin-7(6H)-one $(4, \quad$ sidenafil

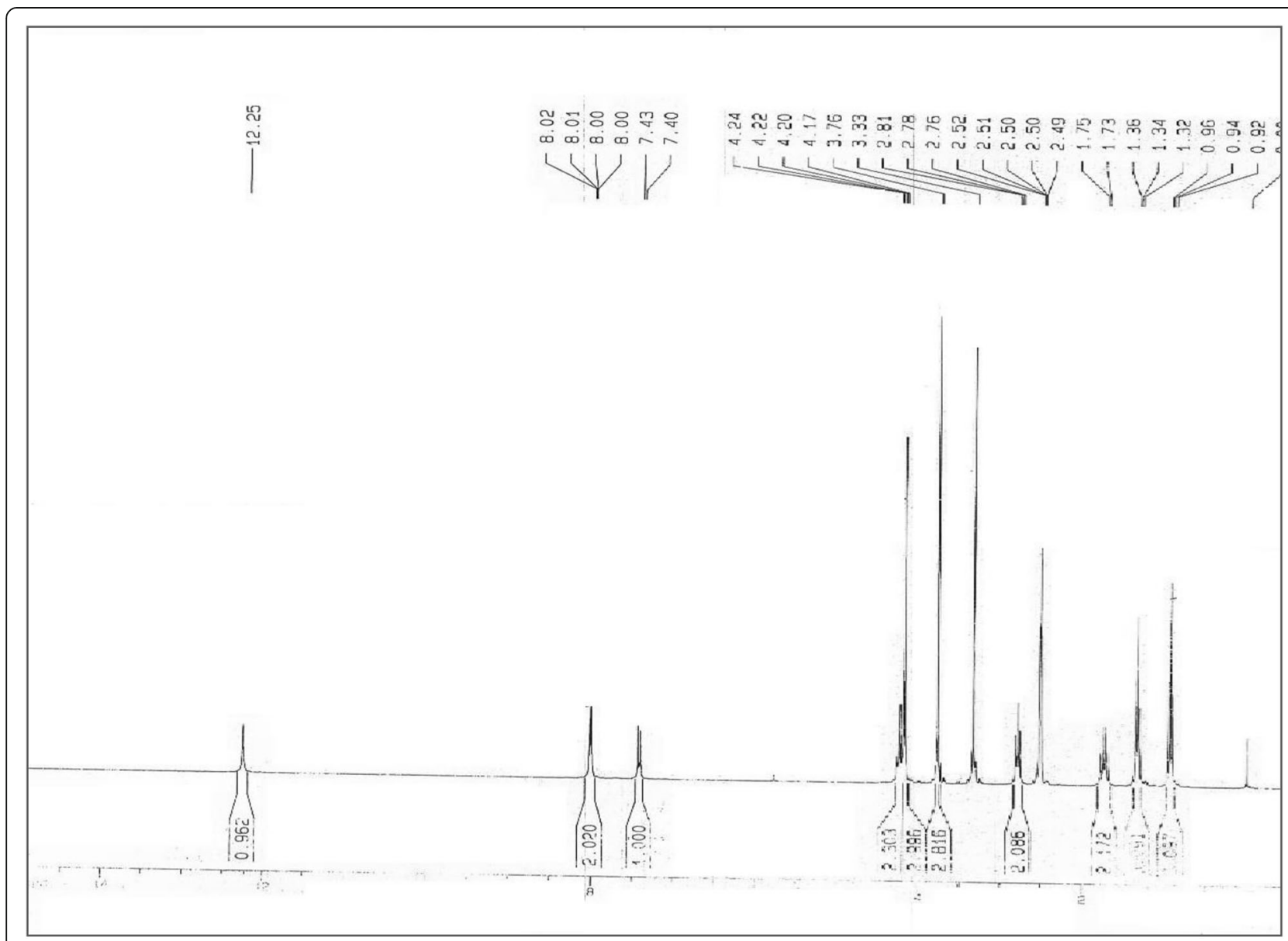

Fig. 1 NMR spectrum of sildenafil sulfonyl methyl ester 


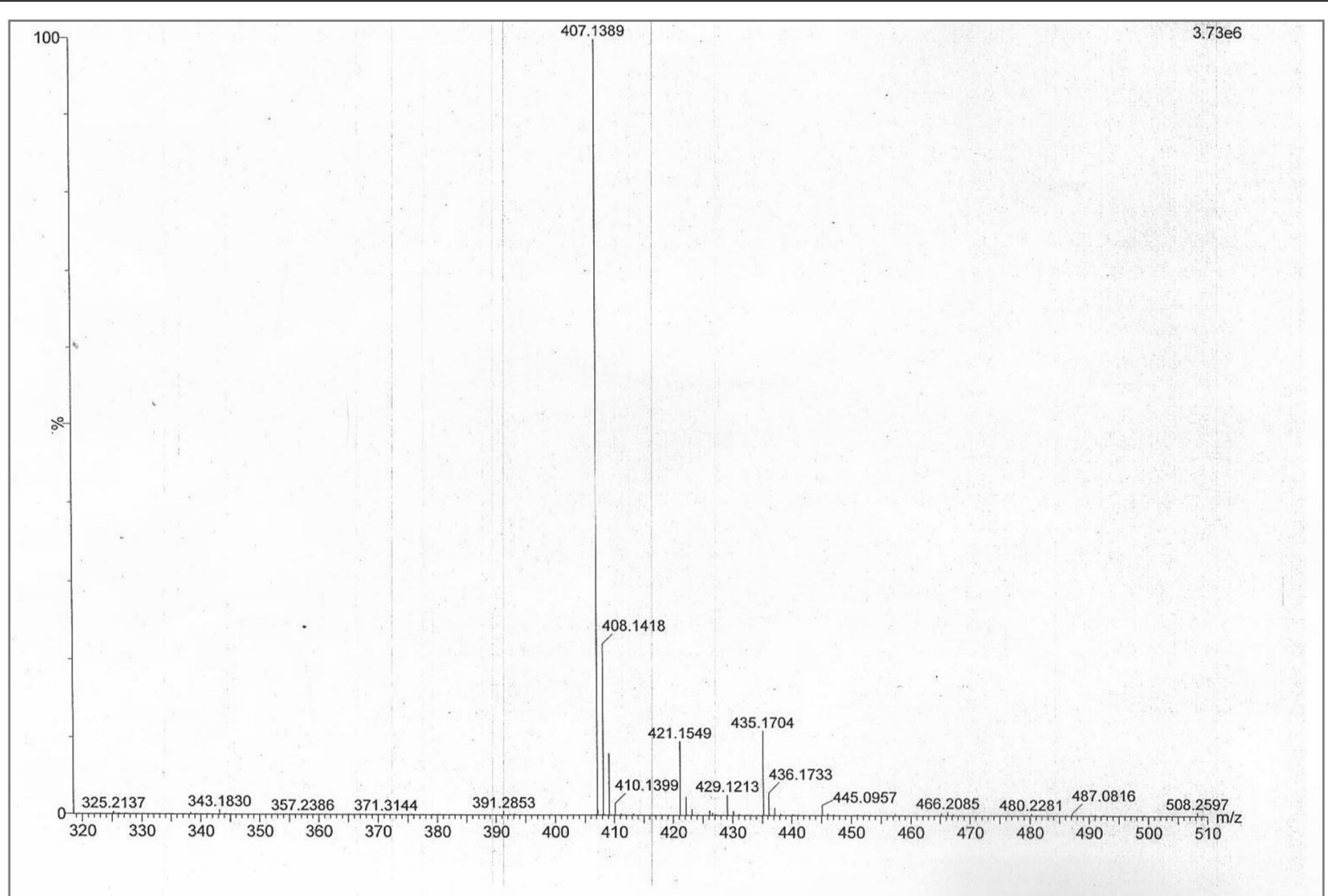

Fig. 2 HRMS spectrum of sildenafil sulfonyl methyl ester

sulfonyl chloride), which is further converted to 5[2-ethoxy-5-(4-methylpiperazinylsulfonyl) phenyl]-1methyl-3-n-propyl-1,6-dihydro-7 $\mathrm{H}$-pyrazolo [4,3-d] pyrimidin-7-one (sildenafil) $\mathbf{5}$ by reacting with $N$ methylpiperazine. Sildenafil is treated with citric acid in water to produce sildenafil citrate $\mathbf{1}$.
Based on the synthetic process of sildenafil citrate, there is a possibility of the formation of sildenafil sulfonyl esters due to the usage of alcohol and its intermediates like sildenafil sulfonyl chloride (4) and sildenafil sulfonic acid (3). So many references [9-12] are available for sildenafil-related substances and its<smiles></smiles>

Scheme 3 Synthetic scheme of sildenafil sulfonyl ethyl ester $\mathbf{7}$. Reagents and conditions: (a) trimetyl orthoformate, ethanol, and dichloromethane and (b) pyridine, ethanol, and dichloromethane 
analogs. To the best of our knowledge, sildenafil sulfonyl ester identification and preparation are not reported anywhere until now.

The chemical names of the sildenafil sulfonyl esters are as follows:

1. Methyl 4-ethoxy-3-(1-methyl-7-oxo-3-propyl-6,7adihydro-3a $H$-pyrazolo[4,3-d]pyrimidin-5-yl)benzenesulfonate (6, sildenafil sulfonyl methyl ester)

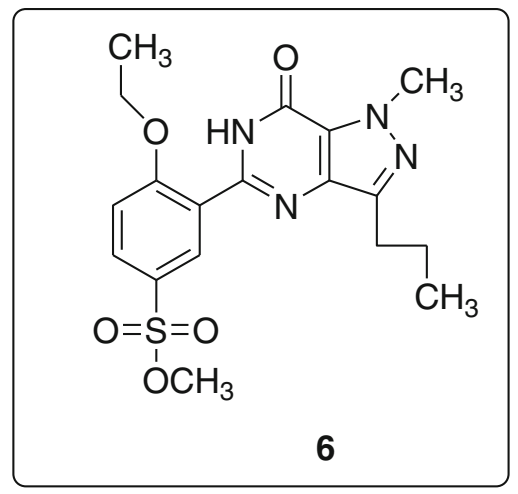

2. Ethyl 4-ethoxy-3-(1-methyl-7-oxo-3-propyl-6,7adihydro-3aH-pyrazolo[4,3-d]pyrimidin-5-yl)benzenesulfonate ( 7 , sildenafil sulfonyl ethyl ester)

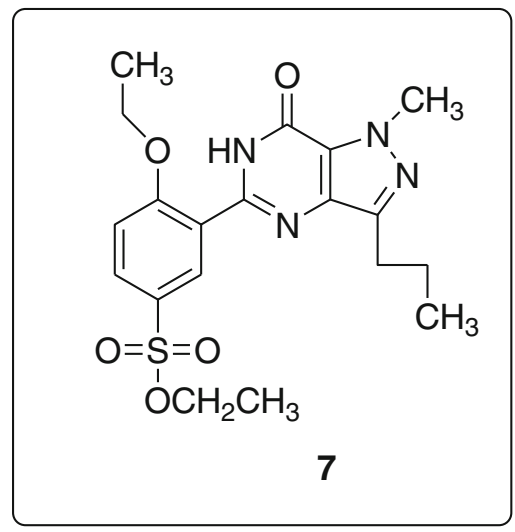

3. Isopropyl 4-ethoxy-3-(1-methyl-7-oxo-3-propyl6,7a-dihydro-3a $H$-pyrazolo[4,3-d]pyrimidin-5-yl) benzenesulfonate (8, sildenafil sulfonyl isopropyl ester)

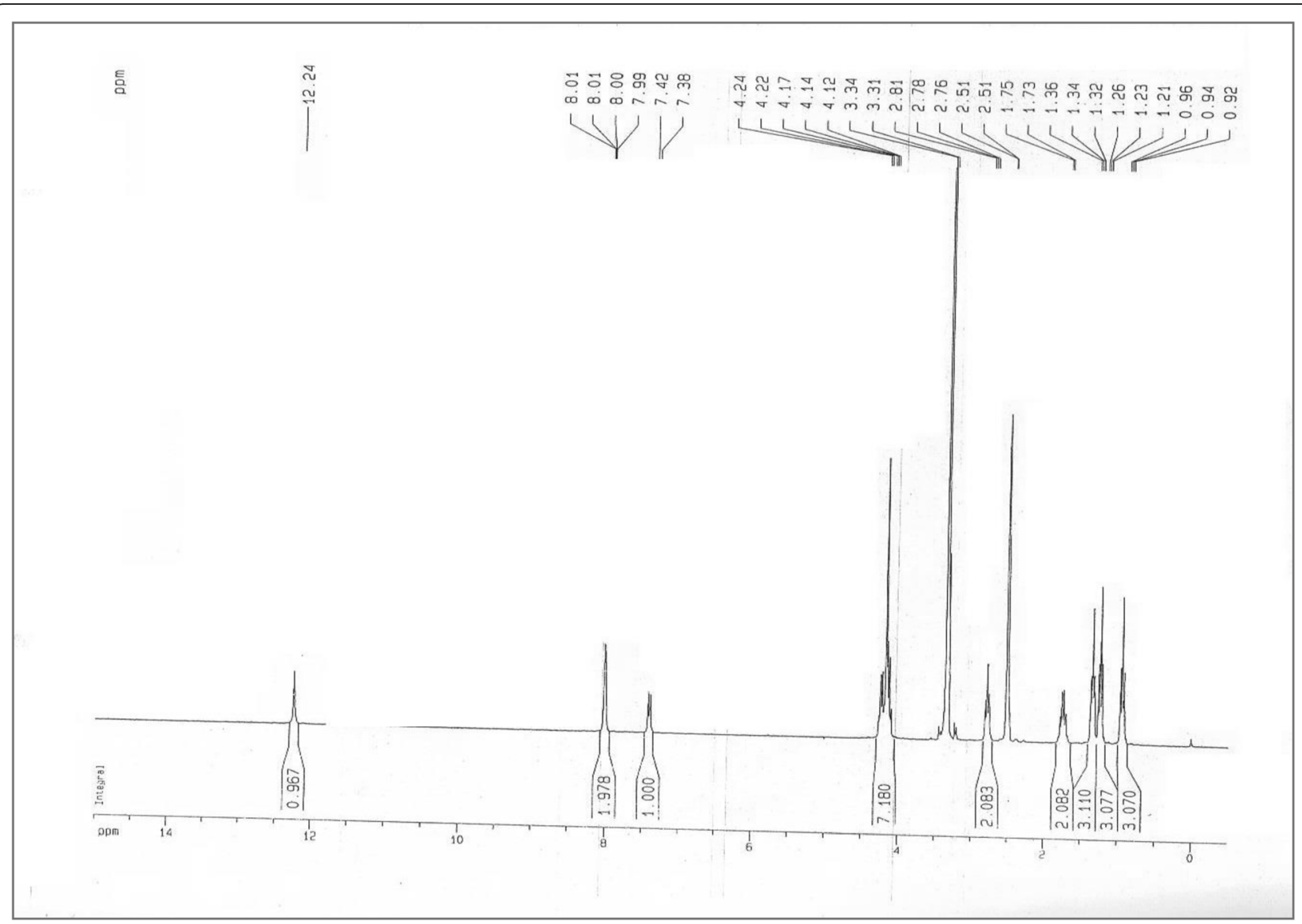

Fig. 3 NMR spectrum of sildenafil sulfonyl ethyl ester 
<smiles>CCCc1nn(C)c2c(=O)[nH]c(-c3cc(S(=O)(=O)OC(C)C)ccc3OCC)nc12</smiles>

\section{Discussion}

Methyl 4-ethoxy-3-(1-methyl-7-oxo-3-propyl-6,7a-dihydro3aH-pyrazolo[4,3-d]pyrimidin-5-yl)benzenesulfonate (sildenafil sulfonyl methyl ester 6)

Sildenafil sulfonyl methyl ester $\mathbf{6}$ was prepared in two ways, i.e., reacting sildenafil sulfonyl chloride 4 with methanol in the presence of pyridine in dichloromethane gives compound $\mathbf{6}$ and the other way [13] is treating sildenafil sulfonic acid $\mathbf{3}$ with trimetyl orthoformate in methanol (as shown in Scheme 2).
The mass spectrum showed a molecular ion at $\mathrm{m} / \mathrm{z}$ $407.1389 \mathrm{amu}\left[(\mathrm{M}+\mathrm{H})^{+}\right]$. The NMR spectrum showed a singlet at $\delta 3.76$, corresponding to the $\mathrm{OCH}_{3}$, confirming the assigned structure 6 (Figs. 1 and 2).

Sildenafil sulfonyl chloride may react with methanol during the preparation of sildenafil citrate and would result in the formation of sildenafil sulfonyl methyl ester.

Sildenafil sulfonyl methyl ester $\mathbf{6}$ should be controlled to $15 \mathrm{ppm}$ in sildenafil citrate drug substance based on the ICH M7 guidelines.

\section{Ethyl 4-ethoxy-3-(1-methyl-7-oxo-3-propyl-6,7a-dihydro- 3aH-pyrazolo[4,3-d]pyrimidin-5-yl) benzenesulfonate (sildenafil sulfonyl ethyl ester 7)}

Sildenafil sulfonyl ethyl ester 7 was prepared in two ways, i.e., reacting sildenafil sulfonyl chloride 4 with ethanol in the presence of pyridine in dichloromethane gives compound 7 , and the other way is treating sildenafil sulfonic acid 3 with trimetyl orthoformate in ethanol (as shown in Scheme 3).

The mass spectrum showed a molecular ion at $\mathrm{m} / \mathrm{z}$ $421.1561 \mathrm{amu}\left[(\mathrm{M}+\mathrm{H})^{+}\right]$. The NMR spectrum showed a triplet at $\delta 1.34$ and quartet at $\delta 4.22$ corresponding to the $\mathrm{CH}_{3}$ and $\mathrm{OCH}_{2}$, respectively, confirming the assigned structure 7 (Figs. 3 and 4).

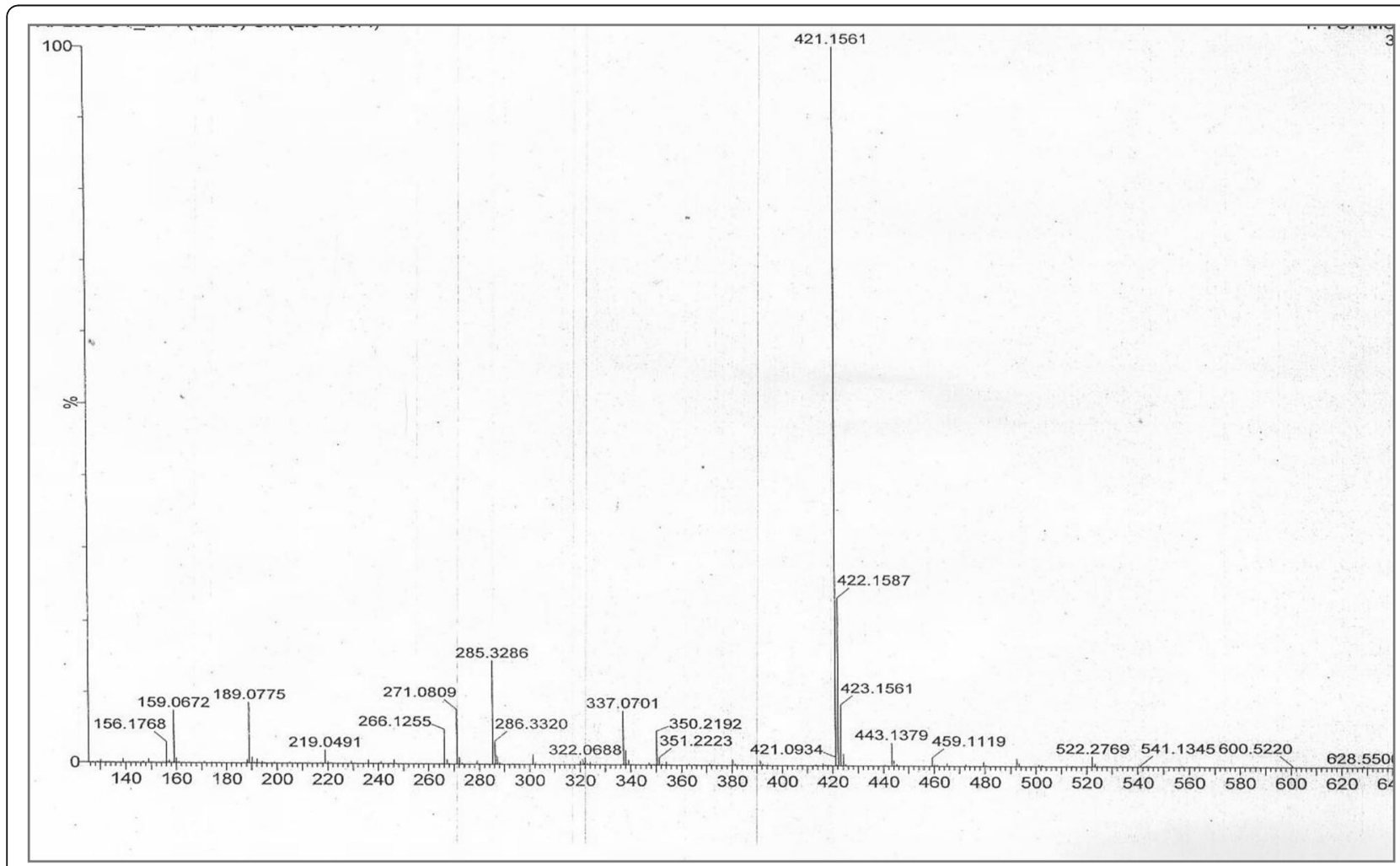

Fig. 4 HRMS spectrum of sildenafil sulfonyl ethyl ester 


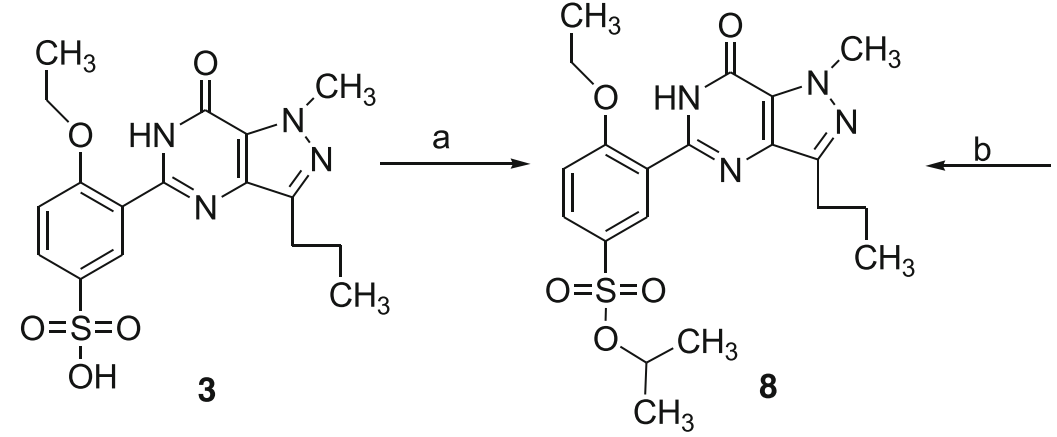<smiles>CCCc1nn(C)c2c(=O)[nH]c(-c3cc(S(=O)(=O)Cl)ccc3OCC)nc12</smiles>

Scheme 4 Synthetic scheme of sildenafil sulfonyl isopropyl ester $\mathbf{8}$. Reagents and conditions: (a) trimetyl orthoformate, isopropyl alcohol, and dichloromethane and (b) pyridine, isopropyl alcohol, and dichloromethane

Sildenafil sulfonyl chloride may react with ethanol during the preparation of sildenafil citrate and would result in the formation of sildenafil sulfonyl ethyl ester.

Sildenafil sulfonyl ethyl ester 7 should be controlled to $15 \mathrm{ppm}$ in sildenafil citrate drug substance based on the ICH M7 guidelines.
Isopropyl 4-ethoxy-3-(1-methyl-7-oxo-3-propyl-6,7adihydro-3aH-pyrazolo[4,3-d]pyrimidin-5-yl) benzenesulfonate (sildenafil sulfonyl isopropyl ester 8) Sildenafil sulfonyl isopropyl ester $\mathbf{8}$ was prepared in two ways, i.e., reacting sildenafil sulfonyl chloride4 with isopropyl alcohol in the presence of pyridine in

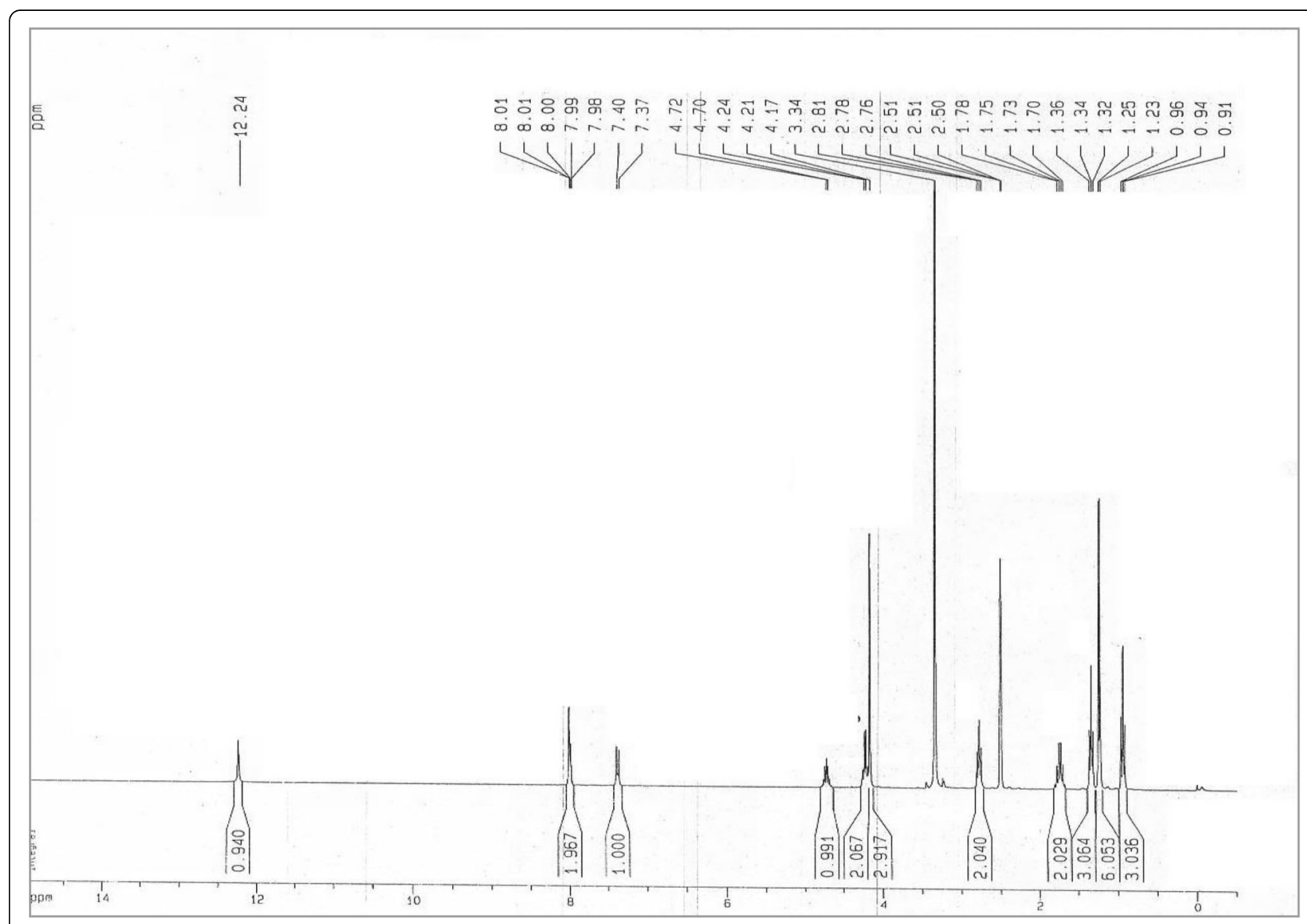

Fig. 5 NMR spectrum of sildenafil sulfonyl isopropyl ester 


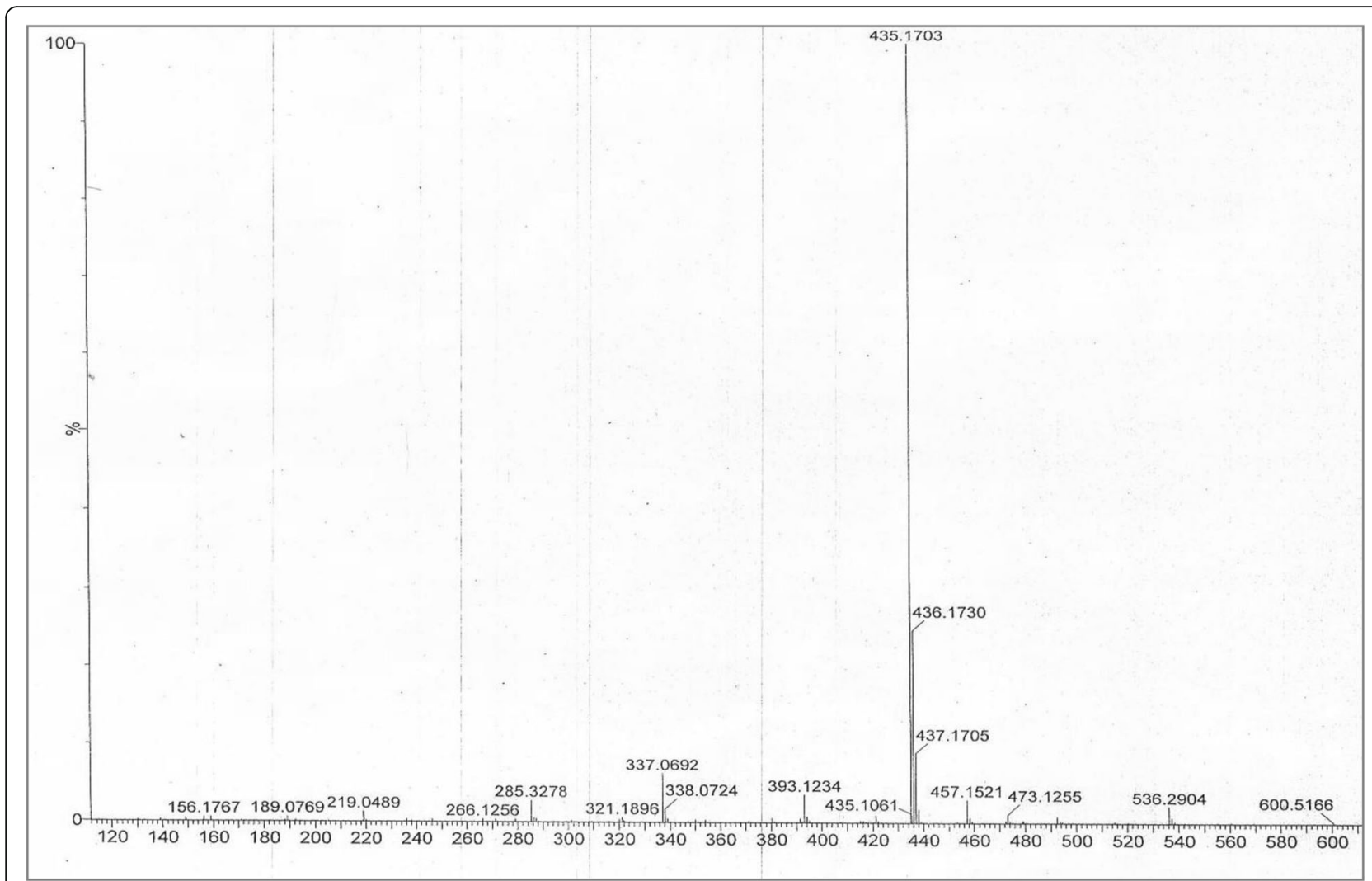

Fig. 6 HRMS spectrum of sildenafil sulfonyl isopropyl ester

dichloromethane gives compound $\mathbf{8}$, and the other way is treating sildenafil sulfonic acid $\mathbf{3}$ with trimetyl orthoformate in isopropyl alcohol (as shown in Scheme 4).

The mass spectrum showed a molecular ion at $\mathrm{m} / \mathrm{z}$ $435.1703 \mathrm{amu}\left[(\mathrm{M}+\mathrm{H})^{+}\right]$. The NMR spectrum showed a doublet at $\delta 1.25$ and multiplet at $\delta 4.72$ corresponding to the $2 \times \mathrm{CH}_{3}$ and $\mathrm{OCH}$, respectively, confirming the assigned structure 8 (Figs. 5 and 6).

Sildenafil sulfonyl chloride may react with isopropanol during the preparation of sildenafil citrate and would result in the formation of sildenafil sulfonyl isopropyl ester.

Sildenafil sulfonyl isopropyl ester $\mathbf{8}$ should be controlled to $15 \mathrm{ppm}$ in sildenafil citrate drug substance based on the ICH M7 guidelines

Further, sildenafil sulfonyl chloride (4) is also a potential genotoxic impurity, and it should be controlled to $15 \mathrm{ppm}$ based on the TTC rule.

\section{Conclusion}

In conclusion, a detailed study of various impurities in sildenafil was conducted in view of the regulatory importance. Different process-related sulfonyl esters in sildenafil were identified, synthesized, and characterized by using various spectroscopic techniques like liquid chromatography-mass spectrometry (LCMS), mass, ${ }^{1} \mathrm{H}$ NMR, and FT-IR. These efforts to synthesize and characterize them effectively have proved to be beneficial.

\section{Acknowledgements}

The authors wish to thank the management of Monvi Labs for carrying out this work and giving permission to publish it, and they are also thankful to the authorities of Krishna University and colleagues of the Analytical Research Department (ARD), Monvi Labs, for their cooperation.

\section{Authors' contributions}

RP performed the experiments and wrote the manuscript. SM and RD contributed to the research guidance. VS, VSNM, and KM contributed to the analytical evaluation. All authors read and approved the final manuscript.

\section{Funding}

No funding was available. This research did not receive any funding from funding agencies.

Availability of data and materials

All data provided in the manuscript is available upon request.

Ethics approval and consent to participate Not applicable. 


\section{Consent for publication}

Not applicable.

\section{Competing interests}

The authors declare no competing interests.

\section{Author details}

${ }^{1}$ Research and Development Department, Monvi Labs, 3rd floor, Plot No. 97, Rd. Number 9, ALEAP Industrial Area, Gajularamaram, Hyderabad, Telangana 500090, India. ${ }^{2}$ Krishna University, Machilipatnam, Andhra Pradesh 521001, India.

Received: 3 March 2020 Accepted: 31 August 2020

Published online: 10 November 2020

\section{References}

1. International Conference on Harmonization (ICH) guidelines Q3A (R) impurities in New Drug Substances (2002) ICH guidelines, Geneva

2. International Conference on Harmonization (ICH) guidelines Q2B validation of analytical Procedure (1996) Methodology, Geneva

3. $M 7(R 1)$ assessment and control of DNA reactive (mutagenic) impurities in pharmaceuticals to limit potential carcinogenic risk; ICH guidelines: 2018

4. Raman NVSSS, Prasad AVSS, Ratnakar Reddy K (2011) Strategies for the identification, control and determination of genotoxic impurities in drug substances: a pharmaceutical perspective. J Pharm Biomed Anal 55:662-667. https://doi.org/10.1016/i.jpba.2010.11.039

5. European medicines agency. Guideline on the specification limits for residues of metal catalysts or metal reagents, Doc. Ref. EMEA/CHMP/SWP/ 4446/2000, European Medicines Agency, 2008.

6. Bell A S, Brown D, Terrett N K. (1993) U.S. patent 5,250,534.

7. Dunn PJ (2005) OPRD. 9(1):88-97. https://doi.org/10.1021/op040019c

8. Raghavareddy A V, Srinivas G, Shantankumar K, Josephprabahar K, Sivakumaran M. Indian patent application no.2230/CHE/2010A.

9. Patel PV, Joshi N, Panchal DP (2012) Heterocyclic Lett 2(4):467-478

10. Saravanan M, Satyanarayana B, Pratapreddy P (2011) Synthesis and characterization of potential impurities of sildenafil. Chem Biol Interface 1(2): 177-184

11. Kumar IVS, Ramanjaneyulu GS, Bindu VH (2011) Synthesis of sildenafil citrate and process related impurities. Lett Org Chem 8(9):668-673

12. Ragahavareddy AV, Garaga S, Chandiran T, Badrinadhgupta P, Naidu A (2016) A facile, improved synthesis of sildenafil and its analogues. Sci Pharm 84:447-455. https://doi.org/10.3390/scipharm84030447

13. Padmapriya AA, Just $G$, Lewis NG (1985) A new method for the esterification of sulfonic acids. Synth Commun 15(12):1057-1062. https://doi. org/10.1080/00397918508076842

\section{Publisher's Note}

Springer Nature remains neutral with regard to jurisdictional claims in published maps and institutional affiliations.

\section{Submit your manuscript to a SpringerOpen ${ }^{\circ}$ journal and benefit from:}

- Convenient online submission

- Rigorous peer review

- Open access: articles freely available online

- High visibility within the field

- Retaining the copyright to your article 